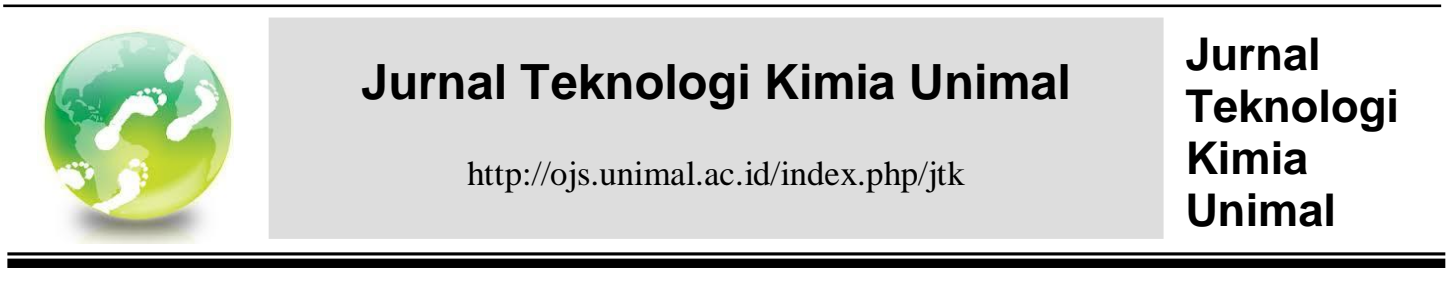

\title{
Pemanfaatan Minyak Sereh (Cymbopogon nardus L) sebagai Antioksidan pada Sabun Mandi Padat
}

\author{
Jalaluddin, Amri Aji, Sari Nuriani \\ Jurusan Teknik Kimia Fakultas Teknik Universitas Malikussaleh \\ email : jlldibr@yahoo.com
}

\begin{abstract}
Abstrak
Sabun merupakan senyawa natrium atau kalium dengan asam lemak dari minyak nabati atau lemak hewani berbentuk padat, lunak atau cair, dan berbusa. Sabun dihasilkan oleh proses saponifikasi, yaitu hidrolisis lemak menjadi asam lemak dan gliserol dalam kondisi basa. Penelitian ini untuk mengetahui pengaruh penambahan minyak sereh pada sabun mandi padat, pengaruh kecepatan putaran pada pembuatan sabun mandi padat,dan menganalisa karakteristik sabun terhadap kadar air, nilai pH, dan asam lemak bebas. Hasil penelitian menunjukkan dengan menggunakan $3 \mathrm{ml}$ minyak sereh pada kecepatan putaran 500 rpm kadar air yang didapat yaitu sebesar 12,8\%, kadar asam lemak bebas sebesar 0,205\%, dan nilai pH sebesar 9,87.
\end{abstract}

Kata Kunci: $\quad$ sabun, saponifikasi, minyak sereh, karakteristik sabun

\section{Pendahuluan}

Sereh adalah gudang nutrisi aromatik penting yang memberikan berbagai manfaat kesehatan. Sereh adalah sumber vitamin penting seperti vitamin A, B1 (thiamin), B2 (riboflavin), B3 (niasin) B5 (asam pantotenat), B6, folat dan vitamin C serta mineral penting seperti potasium, kalsium, magnesium, fosfor, mangan, tembaga, seng dan besi yang dibutuhkan untuk fungsi tubuh yang sehat.

Sereh mengandung antioksidan flavonoid, dan senyawa fenolik seperti luteolin, glikosida, quercetin, kaempferol, elimicin, catecol, asam klorogenat, asam caffeic yang berkhasiat obat. Senyawa utama dalam sereh adalah lemonal atau citral, yang memiliki sifat anti-jamur dan anti-mikroba, serta menyediakan bau lemon yang berbeda-beda.

Sabun mandi merupakan salah satu produk turunan dari minyak. Adapun minyak yang digunakan adalah minyak sawit. Minyak sawit terutama dikenal sebagai bahan mentah minyak dan lemak pangan yang digunakan untuk menghasilkan minyak goreng, shortening, margarin, dan minyak 
makan lainnya. Minyak sawit mengandung asam lemak jenuh dan asam lemak tidak jenuh yang ikatan molekulnya mudah dipisahkan dengan alkali (Amang, 1996). Alkali yang digunakan pada penelitian ini adalah $\mathrm{NaOH}$ karena basa ini akan menghasilkan sabun padat. Secara ideal, sabun mandi padat memiliki kekerasan yang akan memberikan busa yang cukup (yaitu, perilaku sebagai agen pembusa), untuk meningkatkan kemampuan membersihkan dari sabun (Brown et al., 2011).

Berdasarkan latar belakang di atas dapat dirumuskan masalah yaitu bagaimana pembuatan sabun mandi padat minyak sereh sebagai anti oksidan. Berdasarkan perumusan masalah tersebut, maka tujuan penelitian ini adalah untuk mengetahui pengaruh penambahan minyak sereh dan keepatan putaran serta menganalisa karateristik pada sabun mandi padat.

\section{Metodologi Penelitian}

Adapun bahan dan alat yang digunakan pada penelitian ini adalah minyak sawit (sunco), minyak $\mathrm{VCO}, \mathrm{NaOH}$, asam stearat, aquades, minyak sereh gliserin, coco DEA, buret, cawan porselin, corong kaca, erlenmeyer, beaker glass, labu ukur, neraca analitik, pengaduk kaca, pipet tetes, pipet volume, termometer, hot plate, kaca arloji, gelas ukur, filler, spatula, magnetic stirer, dan cetakan sabun.

\subsection{Proses pembuatan Sabun}

Asam Stearat sebanyak 9 gram terlebih dahulu dileburkan pada suhu $60^{\circ} \mathrm{C}$. Setelah ,asam Stearat melebur kemudian ditambahkan minyak sawit sebanyak $30 \mathrm{ml}$ dan minyak VCO sebanyak 2 mlsambil diaduk dengan menggunakan Magnetic Stirer agar campuran homogen.Dan $\mathrm{NaOH}$ dituangkan secara perlahan sebanyak $15 \mathrm{ml}$ pada suhu $70{ }^{\circ} \mathrm{C}$ lalu diaduk selama beberapa menit hingga terbentuk trace.Kemudianditambahkan aquades sebanyak 40 ml.,dan gliserin sebanyak $8 \mathrm{ml}$, Coco-DEA $1 \mathrm{ml}$ sambil diaduk selama 7-10 menit hingga campuran homogen dengan variasi kecepatan pengaduk $250 \mathrm{rpm}$, $350 \mathrm{rpm}$, dan $500 \mathrm{rpm}$. Setelah campuran homogen kemudian ditambahkan minyak sereh yang divariasikan $1 \mathrm{ml}, 2 \mathrm{ml}$, dan $3 \mathrm{ml}$, sambil diaduk hingga 
tercampur sempurna.Campuran kemudian dituangkan kedalam cetakan dan didiamkan selama 24 jam hingga sabun mengeras.

\subsection{TahapAnalisa}

Uji kualitas sabun sereh ditentukan menggunakan SNI 06-3532-1994 berupa uji kadar air, kadar asam lemak, alkali bebas, dan nilai $\mathrm{pH}$.

\section{Uji Kadar Air}

Cawan porselin dipanaskan pada suhu $105^{\circ} \mathrm{C}$ selama setengah jam dan didinginkan dalam desikator selama 15 menit. Kemudian ditimbang cawan porselin kosong yang beratnya telah konstan. Sampel sebanyak 5 gram yang sudah ditimbang dimasukkan kedalam cawan porselin. Kemudian dipanaskan kembali selama 1 jam dengan suhu $105^{\circ} \mathrm{C}$. Bila timbul gelembung maka dihancurkan dengan batang pengaduk lalu dipanaskan lagi dan ditimbang hingga bobot tetap.

$$
\text { Kadar air }=\frac{\text { kekurangan bobot }}{\text { gr sampel }} \times 100 \%
$$

Keterangan: kekurangan bobot $=$ berat sampel-berat akhir sabun

\section{Uji Kadar Asam Lemak Bebas}

Diambil $100 \mathrm{ml}$ etanol dimasukkan kedalam Erlenmeyer $250 \mathrm{ml}$ kemudian dipanaskan sampai mendidih. Kemudian ditambahkan $0,5 \mathrm{ml}$ phenopthalein dan dinginkan sampai suhu $70^{\circ} \mathrm{C}$ kemudian dinetralkan dengan $\mathrm{NaOH}$-etanol $0,1 \mathrm{~N}$. Sampel ditimbang sebanyak 5 gram kemudian dimasukkan kedalam alkohol netral yang diatas lalu dipanaskan selama 30 menit sampai mendidih. Larutan berwarna merah (bersifat alkalis) didinginkan sampai suhu $70^{\circ} \mathrm{C}$ dan dititrasi dengan $\mathrm{NaOH}-$ etanol 0,1 $\mathrm{N}$ sampai timbul warna yang tahan selama 15 detik.

$$
\text { Asam Lemak Bebas }=\frac{V \times N \times 0,205}{W} \times 100 \%
$$

Keterangan:

$\mathrm{V}=$ Volume $\mathrm{NaOH}$-etanol $0,1 \mathrm{~N}$ yang digunakan $(\mathrm{ml})$

$\mathrm{N}=$ Normalitas $\mathrm{NaOH}$-etanol $0,1 \mathrm{~N}$ yang digunakan

$\mathrm{W}=$ Bobot sampel 


\section{$0,205=$ Bobot setara $\mathrm{NaOH}$}

\section{Uji Nilai $\mathrm{pH}$}

Sebelum dilakukan pengukuran dengan $\mathrm{pH}$ meter maka terlebih dahulu $\mathrm{pH}$ meter dikalibrasi dengan larutan buffer $\mathrm{pH} 4$ dan 10. Selanjutnya elektroda dibersihkan menggunakan aquades. Sampel ditimbang sebanyak 1 gram kedalam beaker glass. Kemudia aquades sebanyak $9 \mathrm{ml}$ dimasukkan kedalam beaker glass, lalu dipanaskan dan dikocok. Elektroda yang telah bersih kemudian dicelupkan kedalam sampel sabun. Kemudian dicatat nilai $\mathrm{pH}$ yang didapat setelah angka pada $\mathrm{pH}$ meter stabil.

\section{Hasil dan Diskusi}

\subsection{Pengaruh Kecepatan Pengaduk dan Volume Minyak Sereh terhadap Kadar Air}

Kadar air merupakan jumlah kadar air yang terkandung dalam suatu bahan (Masri, 2009). Keberadaan air dalam suatu produk sangat menentukan mutu produk tersebut tak terkecuali sabun mandi padat. Prinsip penentuan kadar air adalah pengukuran berat setelah dilakukan pengeringan selama 1 jam dengan suhu $105^{\circ} \mathrm{C}$. Berdasarkan SNI 06-3532-1994, kadar air yang diperoleh dalam sediaan sabun padat maksimal $15 \%$. Kadar air yang diperiksa terhadap sabun yang dibuat menunjukkan hasil penelitian tidak sesuai dengan ketentuan SNI. Adapun hasil kadar air yang diapatkan pada penelitian ini dapat dilihat pada Gambar 1.

Berdasarkan Gambar 1, kadar air terendah yang didapatkan pada penelitian ini adalah sebesar 5,8 \% yaitu pada volume minyak sereh $3 \mathrm{ml}$ dengan kecepatan pengadukan $250 \mathrm{rpm}$, sedangkan kadar air tertinggi yaitu pada volume minyak sereh $1 \mathrm{ml}$ dengan kecepatan putaran $350 \mathrm{rpm}$ yaitu sebesar 23,8 \%. Dimana, semakin banyak volume minyak sereh yang digunakan maka kadar air yang didapat semakin sedikit, serta semakin besar kecepatan pengaduk maka semakin kecil pula kadar air yang diperoleh. Tingginya kadar air yang didapat menyebabkan sabun mudah berbau tengik. Dengan adanya penambahan antioksidan minyak sereh maka bau tengik pada sabun dapat dikurangi. 
Spitz (1996) berpendapat kuantitas air yang terlalu banyak dalam sabun akan membuat sabun tersebut mudah menyusut dan tidak nyaman saat akan digunakan. Keberadaan air dan udara dapat memicu terjadinya oksidasi. Ketaren (1986) menjelaskan bahwa proses oksidasi dapat berlangsung apabila terjadi konta antara sejumlah oksigen dan minyak atau lemak. Oksidasi biasanya dimulai dengan pembentukan peroksida. Tingkat selanjutnya ialah terurainya asam-asam lemak disertai dengan konversi hidroksida menjadi aldehid dan keton serta asamasam lemak bebas. Senyawa aldehid dan keton yang dihasilkan dari lanjutan reaksi oksidasi ini memiliki sifat mudah menguap dan seperti alkohol.

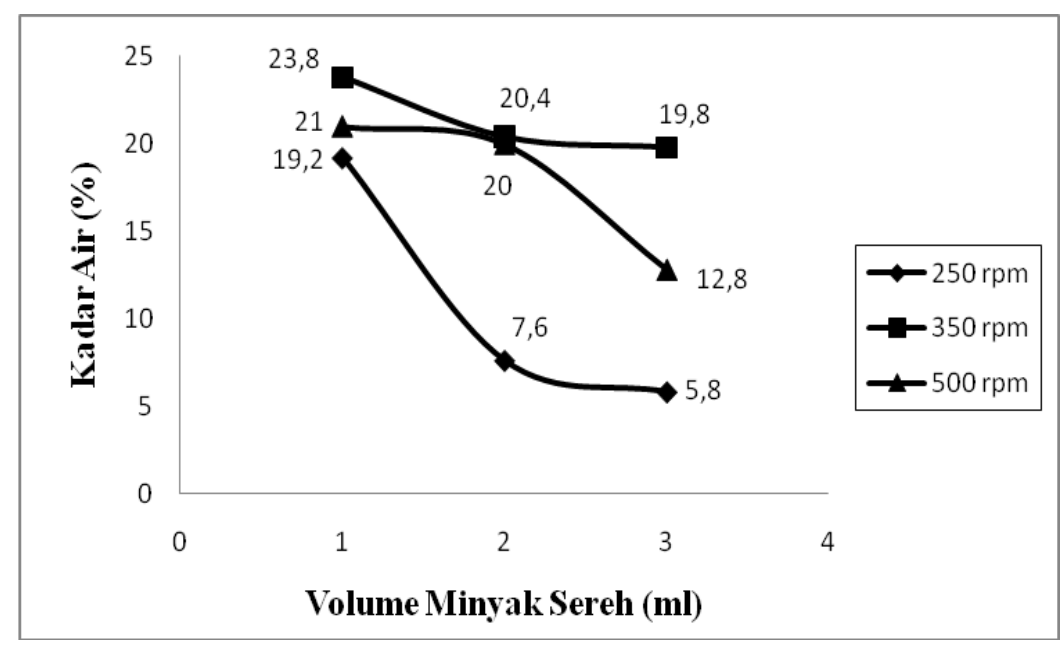

Gambar 1 Hubungan Kadar Air dengan Kecepatan Pengadukan dan Volume Minyak Sereh pada Pembuatan Sabun Mandi Padat

\subsection{Pengaruh Kecepatan Pengaduk dan Volume Minyak Sereh terhadap Asam Lemak Bebas}

Asam lemak bebas adalah asam lemak yang berada dalam sampel sabun, tetapi tidak terikat sebagai senyawa natrium ataupun sebagai senyawa trigliserida atau lemak netral. Asam lemak bebas merupakan komponen yang tidak diinginkan dalam proses pembersihan. Adapun kadar asam lemak bebas yang didapatkan pada penelitian ini dapat dilihat pada Gambar 2.

Analisa kadar asam lemak bebas pada sampel sabun adalah dengan mendidihkan sabun yang ditambahkan $25 \mathrm{ml}$ etanol netral dengan penambahan 
fenolftalein sebanyak 3 tetes. Asam lemak bebas yang larut dalam etanol netral kemudian dititrasi dengan Natrium Hidroksida. Berdasarkan grafik 3.2 maka didapatlah kadar asam lemak bebas yang paling tinggi yaitu pada volume minyak sereh $3 \mathrm{ml}$ dengan kecepatan pengadukan $500 \mathrm{rpm}$ dengan kadar asam lemak bebas $0,205 \%$. Sedangkan kadar asam lemak bebas yang rendah berada pada kecepatan pengaduk $250 \mathrm{rpm}$ dengan volume minyak sereh $1 \mathrm{ml}$ yaitu sebesar 0,041\%. Kenaikan kandungan asam lemak bebas ini dipengaruhi oleh tidak sanggupnya $\mathrm{NaOH}$ mengikat minyak yang berlebih sehingga asam lemak bebas masih terkandung didalam sabun. Hasil analisa ini menunjukkan bahwa jumlah asam lemak bebas yang terdapat pada pembuatan sabun mandi padat ini sudah memenuhi syarat mutu SNI yaitu sebesar $<2,5 \%$.

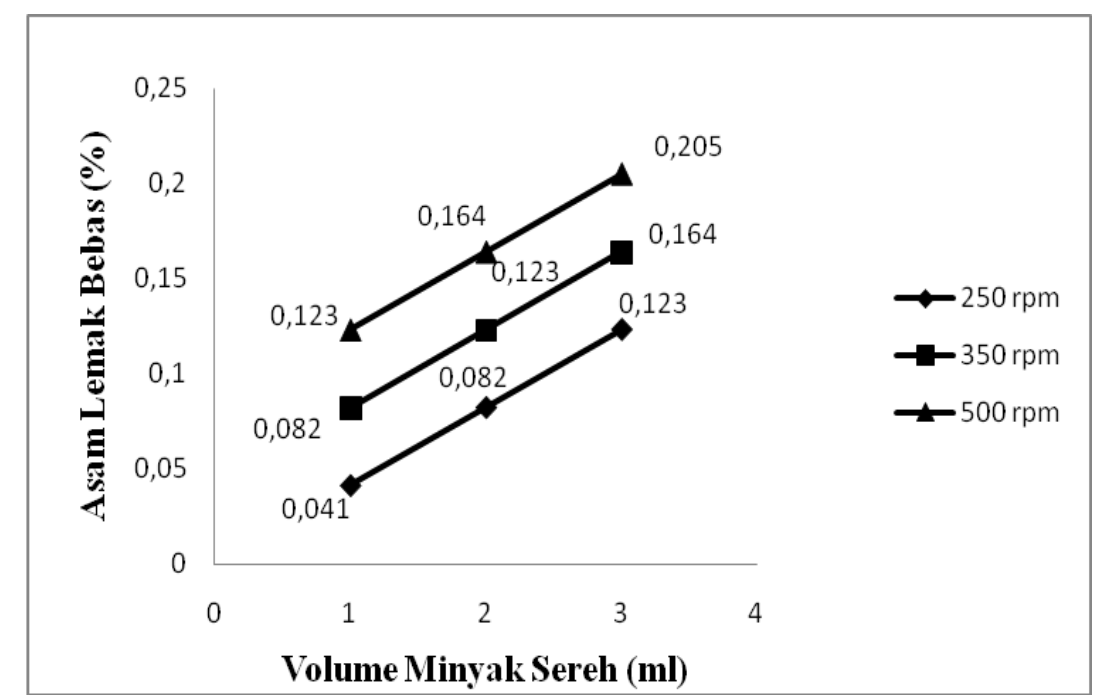

Gambar 2 Hubungan Kadar Asam Lemak Bebas dengan Kecepatan Pengadukan dan Volume Minyak Sereh pada Pembuatan Sabun Mandi Padat

Adanya asam lemak bebas pada sabun disebabkan karena reaksi penyabunan yang tidak sempurna. Sabun yang mengandung kadar asam lemak bebas cenderung berbau tengik dan menghambat proses pembersihan permukaan kulit oleh sabun. Bahan baku yang berlebih juga akan menyebabkan adanya asam lemak bebas pada sabun dikarenakan $\mathrm{NaOH}$ tidak sanggup mengikat seluruh bahan baku (minyak). 


\subsection{Pengaruh Kecepatan Pengaduk dan Volume Minyak Sereh terhadap Nilai pH (Derajat Keasaman)}

Derajat keasaman atau $\mathrm{pH}$ digunakan untuk menyatakan tingkat keasaman atau kebasaan suatu larutan. Dimana, yang dimaksud dengan keasaman adalah konsentrasi ion hidrogen dalam pelarut air. pH sabun yang tinggi disebabkan oleh terjadinya hidrolisis sabun. Nilai derajat keasaman $(\mathrm{pH})$ yang paling baik ialah sabun yang memiliki pH sekitar 7. Sedangkan sabun komersil yang biasa lainnya memiliki pH sekitar 9 - 11. Sabun dengan pH netral merupakan sabun yang baik, karena lembut untuk kulit. Kulit normal memiliki pH sekitar 5. Penggunaan sabun akan membuat nilai $\mathrm{pH}$ kulit meningkat untuk sementara. Akan tetapi, kenaikan $\mathrm{pH}$ pada kulit tidak akan melebihi 7 (Jellinek, 1970).

Hasil analisa untuk sabun mandi padat memiliki pH sekitar 9 - 10,26. Hasil ini menunjukkan bahwa nilai $\mathrm{pH}$ sabun padat cukup baik dan memenuhi syarat mutu sabun berdasarkan SNI. Menurut Wasiatmadja (1997), pH yang sangat tinggi atau rendah dapat meningkatkan daya absorbsi kulit sehingga kulit menjadi iritasi. Kadar nilai $\mathrm{pH}$ pada penelitian sabun mandi padat dengan penambahan minyak sereh sebagai antioksidan dapat dilihat pada Gambar 3.

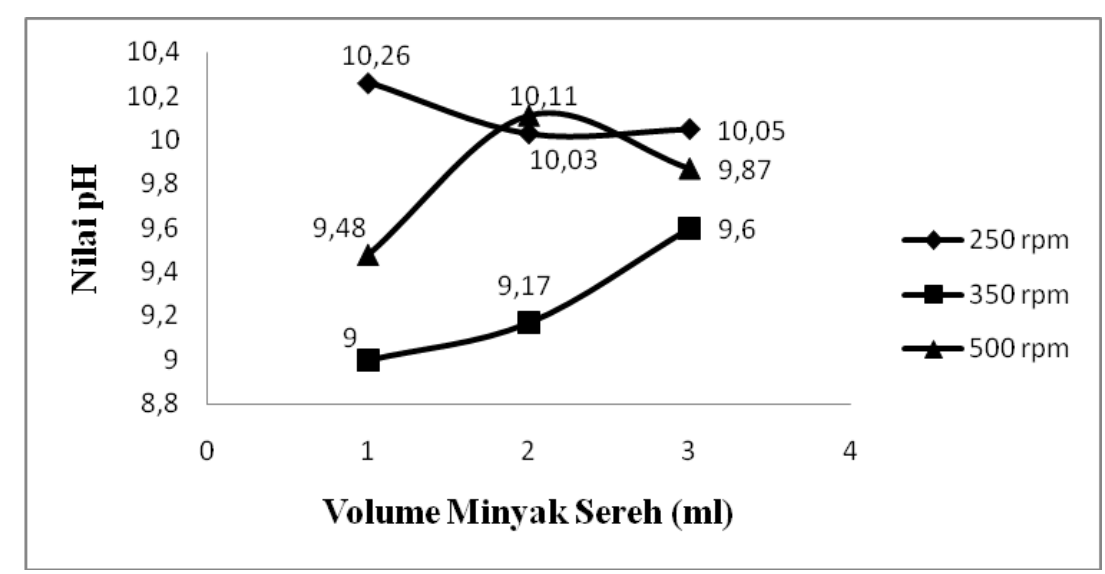

Gambar 3 Hubungan Kadar Nilai pH dengan Kecepatan Pengadukan dan Volume Minyak Sereh pada Pembuatan Sabun Mandi Padat

Berdasarkan Gambar 3 dapat dilihat bahwa nilai $\mathrm{pH}$ tertinggi dari sabun mandi padat dengan penambahan minyak sereh sebagai antioksidan yaitu pada volume minyak sereh $1 \mathrm{ml}$ dengan kecepatan putaran $250 \mathrm{rpm}$ dengan nilai $\mathrm{pH}$ 
sebesar 10,26. Sedangkan nilai $\mathrm{pH}$ terendah terdapat pada volume minyak sereh 1 $\mathrm{ml}$ dengan kecepatan putaran $350 \mathrm{rpm}$ dengan nilai $\mathrm{pH}$ sebesar 9,0. Volume minyak sereh yang terbaik yang didapatkan yaitu pada volume minyak sereh $1 \mathrm{ml}$ dengan kecepatan pengaduk $350 \mathrm{rpm}$. Hal dikarenakan pada volume minyak sereh $1 \mathrm{ml}$ dan kecepatan $350 \mathrm{rpm}$ memiliki $\mathrm{pH}$ yang cocok untuk digunakan pada kulit.

\section{Simpulan dan Saran}

\subsection{Simpulan}

Berdasarkan hasil penelitian maka dapat disimpulkan sebagai berikut:

1. Bahan baku (minyak) yang berlebih menyebabkan adanya asam lemak bebas pada sabun.

2. Semakin besar kecepatan pengaduk yang diberikan maka semakin sedikit nilai kadar air yang didapatkan. Nilai kadar air terkecil yang didapatkan yaitu sebesar $12,8 \%$.

3. Nilai $\mathrm{pH}$ yang paling rendah yaitu pada volume minyak sereh $1 \mathrm{ml}$ dengan kecepatan pengadukan $350 \mathrm{rpm}$ yaitu sebesar 9. Nilai $\mathrm{pH}$ yang paling tinggi yaitu pada volume minyak sereh $1 \mathrm{ml}$ dengan kecepatan pengadukan $250 \mathrm{rpm}$ yaitu sebesar 10,26.

\subsection{Saran}

Penelitian ini masih dapat dikembangkan untuk mendapatkan formulasi yang lebih seimbang antara lemak dengan basa dalam sabun mandi padat sereh.

\section{Daftar Pustaka}

Amang, B., Pantjar, S., dan Anas, R. 1996. Ekonomi Minyak Goreng di Indonesia. Jakarta: IPB Press.

Brown et al. 2011. Nutrition Thriugh Life Cycle, 3 ${ }^{\text {rd }}$. Ed. USA: Thomson Wadsworth.

Dalimartha, S. dan Soedibyo, M. 1999. Awet Muda dengan Tumbuhan Obat dan Diet Supleme. Jakarta: Trubus Agriwidya.

Darmawati. 2014. Pemanfaatan Minyak biji alpukat Sebagai Bahan aditif pada Pembuatan Sabun Transparan. Aceh Utara: Universitas Malikussaleh. 
Fesseden. J. Ralph, 1992. Analisa dan Pembuatan Sabun Mandi. Medan: Universitas Sumatera Utara.

Jellinek, S. 1970. Formulation and Function of Cosmetic. Translated. New York: Wiley interscience.

Hambali, E., A. Suryani dan M.Rivai. 2005. Membuat Sabun Transparan untuk Gift dan Kecantikan. Jakarta: Penebar Swadaya.

Ketaren, S. 1986. Pengantar teknologi Minyak dan Lemak Pangan. Jakarta: Universitas Indonesia.

Kun Harisha, Agus Sriyanto. Jurusan Teknik Kimia. $\quad$ Fakultas Teknik. Surakarta: Universitas Muhammadiyah Surakarta.

Masri, Pradipto. 2009.Pemanfaatan Minyak Jarak Pagar (jatropha curcas l.) Sebagai Bahan Dasar Sabun Mandi. Skripsi.Bogor : IPB.

Nugraha, Febriyawati Cahyanti. 2015. Karakteristik Sabun Sereh pada Perlakuan Nisbah Konsentrasi Minyak Kelapa-Asam Stearat dan Gula Pasir HalusEtanol. Fakultas teknologi Pertanian: Unud

Pahan, Iyung. 2006. Panduan Lengkap Kelapa Sawit Manajemen Agribisnis dari Hulu Hingga Hilir. Jakarta: Swadaya.

Pahan, Iyung. 2007. Panduan Lengkap Kelapa Sawit. Jakarta: Penebar Swadaya.

Permono, A. 2001. Pembuatan Sabun Mandi Padat. Jakarta: Swadya.

Pujimulyani, Dwiyati. 2003. Teknologi Pengolahan Sayur-Sayuran dan BuahBuahan. Grada Ilmu: Yogyakarta.

Rosen, MJ. 1987. Surfaktan sebagai Foaming Agent.

Wasiaatmadja. S. M. 1997. Formula Dasar Sabun. Institut Pertanian Bogor.

Wibisono. 2011. Tanaman Obat KeluargaTanaman Obat Keluarga Berkhasiat. Ungaran: VIVO Publisher.

Wiliam B. Cuvelier M.E. Berset C., (1995), Use of a free radical method to evaluate antioxidant activity. Lebensm Wiss. Technol 28, zelenaplus.com. diakses 25 Maret 2013.

Winarsi. H. 2007. Antioksidan Alami dn Radikal Bebas. Yogyakarta: Penerbit Kanasius. 